\title{
Unclassified myelodysplastic syndrome
}

INSERM

\section{Source}

INSERM. (1999). Orphanet: an online rare disease and orphan drug data base.

Unclassified myelodysplastic syndrome. ORPHA:98827

Unclassified myelodysplastic syndrome (MDS-U) is a subtype of myelodysplastic

syndrome (MDS; see this term) with atypical features of uncertain clinical significance. 